\title{
ANALISIS KESALAHAN SISWA KELAS IV SD MENYELESAIKAN SOAL KPK DAN FPB BERDASARKAN PROSEDUR NEWMAN
}

\author{
Dinda Seltina Febriyanti, Hamdani, Tahmid Sabri \\ Program Studi Guru Sekolah Dasar FKIP UNTAN Pontianak \\ Email:f1082161050@gmail.com
}

\begin{abstract}
This study aims to analyze the types of errors and the factors that cause students to make mistakes in solving the LCM (Least Common Multiple) and GCD (Greatest Common Divisor) questions based on Newman's procedures in grade IV State Elementary School 01 Balai Karangan. The research method used in this research is descriptive qualitative. The research subjects in this study were the fourth grade students of State Elementary School 01 Balai Karangan, totaling 28 students. Data collection techniques in this study were tests and interviews. Based on the results of the study, the errors made by students were (1) misunderstood the question as much $55,36 \%$, (2) transformation error as much 58,93\%, (3) process skill error as much $83,04 \%$, and (4) errors in writing the final answer as much 88,39\%. While the factors that cause students to make mistakes are internal factors, namely from the lack of ability of the students themselves and external factors, namely from lack of attention, guidance, and motivation from teachers and families.
\end{abstract}

\section{Keyword: Error Analysis, Prosedur Newman, Error Type, Causative Factor, LCM and GCD.}

Matematika diajarkan di setiap jenjang pendidikan yang dimulai dari jenjang paling dasar yaitu Sekolah Dasar (SD). Hal itu dilakukan agar siswa dibekali pemikiran yang kreatif, logis, kritis, analitis, dan sistematis. Akan tetapi, sangat disayangkan nilai matematika siswa sering ditemukan berada di bawah nilai kriteria ketuntasan minimum (KKM). Hadi dan Novaliyoso (2019) mengemukakan bahwa "hasil terbaru, yaitu TIMSS 2015 Indonesia berada di peringkat 44 dari 49 negara" (p.563).

Rendahnya hasil belajar siswa terhadap matematika dapat dipengaruhi oleh sejauhmana siswa tersebut menguasai pemahaman konsep dan keterampilan operasi hitung. Sebagaimana dikatakan oleh Muhsetyo (2014) bahwa "Ciri keabstrakan matematika yang tidak sederhana menyebabkan matematika tidak mudah untuk dipelajari, dan pada akhirnya banyak peserta didik yang kurang tertarik terhadap matematika (masih lebih untuk daripada membenci atau "alergi" terhadap matematika) (p.1.2). Salah satu materi matematika yang bisa dikatakan tidak mudah untuk dipelajari adalah kelipatan persekutuan terkecil (KPK) dan faktor persekutuan terbesar (FPB).

KPK dan FPB sangat berguna dalam kehidupan sehari-hari. Contohnya penerapan FPB, yaitu untuk menentukan banyaknya maksimal kantong yang dibutuhkan untuk membagi buah-buahan agar sama banyak tiap kantongnya. Sedangkan penerapan KPK, yaitu untuk menentukan kapan lampu berkedip bersamaan jika lampu dinyalakan pada waktu yang berbeda-beda. Namun pada kenyatannya masih banyak siswa kelas IV yang mengalami kesulitan dalam menyelesaikan permasalahan pada materi KPK dan FPB terutama yang berbentuk soal uraian. 
Untuk melihat kemampuan pemecahan masalah matematika siswa, salah satu caranya adalah melalui pemberian tes yaitu soal matematika yang berbentuk uraian. Soal uraian memaparkan jawaban yang menuntut pada langkah-langkah dalam penyelesaiannya terutama pada soal matematika. tidak dipungkiri banyak siswa yang nilainya selalu rendah bila dihadapkan dengan soal uraian, berbeda dengan soal pilihan ganda yang bisa mengandalkan keberuntungan tebakan.

Rendahnya nilai hasil belajar yang diperoleh dari soal uraian menunjukkan bahwa siswa masih cenderung melakukan kesalahan-kesalahan dalam menyelesaikan permasalahan yang diberikan terutama pada langkah-langkah penyelesaiannya. Menganalisis jenis-jenis kesalahan yang dilakukan siswa dalam menjawab dan menyelesaikan masalah matematika sangat membantu dalam menentukan strategi yang diambil dalam pembelajaran ke depannya. Sebagaimana Suryanto dan Djatmiko (2012) menyampaikan bahwa "Melihat pola kesalahan yang umum dilakukan siswa dalam menjawab dan menyelesaikan masalah untuk materi serta kompetensi tertentu sangat membantu guru dalam melakukan perbaikan dan penyesuaian program belajar mengajar" (p.6.11).

Hasil pra-riset masih banyak siswa yang tidak menguasai materi matematika salah satunya materi KPK dan FPB. Berdasarkan hasil belajar dalam bentuk nilai murni oleh guru kelas, masih banyak siswa yang nilai matematikanya berada di bawah KKM. Ini terlihat saat tugas matematika materi KPK dan FPB diberikan, kebanyakan nilai siswa banyak yang rendah dan sangat memperihatinkan. Pada saat ditanya tentang cara guru menjelaskan langkah-langkah pengerjaan KPK dan FPB mendekati langkah-langkah prosedur Newman namun tidak terlalu dipermasalahkan oleh guru kelas tentang jawaban siswa yang penting ada langkah-langkah penyelesaiannya saja. Untuk hasil nilai tugas harian siswa untuk KPK dan FPB dari beberapa portofolio yang tersimpan oleh guru kelas, terlihat masih banyak siswa yang tidak dapat menyelesaikan soal KPK dan FPB sesuai dengan langkah-langkah yang diajarkan. Namun sayangnya, guru kelas tidak berusaha mencari tahu jenis dan penyebab siswa melakukan kesalahan lebih lanjut. Padahal, jika bisa memperbaiki kesalahan yang sama maka kesalahan tersebut tidak akan terus berlanjut di kemudian hari.

Untuk mengetahui jenis dan penyebab kesalahan siswa dalam mengerjakan soal materi KPK dan FPB dapat dilakukan dengan menganalisis kesalahan siswa salah satunya dengan prosedur Newman. Prakitipong dan Nakamura (2006) menjelaskan bahwa "The Newman Procedure is a method that analyzes errors in sentence problems" (p.113). Yang artinya prosedur Newman adalah sebuah metode untuk menganalisis kesalahan dalam soal uraian. Sebagaimana Jha (2012) memaparkan analisis kesalahan berdasarkan prosedur Newman diantaranya "reading error (kesalahan membaca), Comprehesion error (kesalahan memahami soal), transformation error (kesalahan transformasi), process skill error (kesalahan keterampilan proses), and encoding error (kesalahan penulisan jawaban akhir)" (p.18).

Humaerah (2017) dalam penelitiannya memaparkan bahwa kesalahan terbesar dilakukan pada tahap penulisan jawaban akhir yaitu sebanyak $100 \%$ sedangkan kesalahan terkecil dilakukan pada tahap membaca yaitu sebanyak 17\%. Faktor penyebab kesalahan membaca yaitu siswa belum lancar membaca dan kurangnya pengetahuan siswa mengenai simbol-simbol yang biasa digunakan dalam soal matematika sedangkan penyebab kesalahan penulisan jawaban akhir yaitu akibat dari kesalahan sebelumnya dan tidak paham dengan hal yang ditanyakan dalam soal.

Ayuwirdayana (2019) dalam penelitiannya menyebutkan penyebab kesalahan, yaitu: (1) Kesalahan memahami masalah penyebabnya adalah siswa kurang memahami maksud soal sehingga menyebabkan siswa tidak dapat menentukan apa yang diketahui dan ditanyakan soal. (2) Kesalahan transformasi penyebabnya adalah siswa kurang paham dalam memilih 
pendekatan yang akan digunakan dalam menyelesaikan soal dan lemahnya kemampuan siswa dalam mengubah soal cerita matematika menjadi model matematika. (3) Kesalahan kemampuan proses penyebabnya adalah siswa salah dalam melakukan perhitungan dan kurang cermat dalam menyelesaikan pekerjaan. Kesalahan ini juga disebabkan lemahnya kemampuan siswa dalam melakukan operasi hitung bentuk aljabar. (4) Kesalahan penulisan jawaban akhir penyebabnya adalah siswa tidak menemukan jawaban akhir, tidak tepat dalam menuliskan kesimpulan, siswa mengabaikannya karena merasa tidak perlu dan tergesa-gesa dalam menyelesaikannya sehingga siswa keliru dalam menuliskan jawaban akhir.

Berdasarkan paparan di atas, maka peneliti tertarik melakukan penelitian yang berjudul Analisis Kesalahan Siswa Menyelesaikan Soal KPK Dan FPB Berdasarkan Prosedur Newman Kelas IV SD.

\section{METODE PENELITIAN}

Penelitian ini menggunakan metode deskriptif dengan pendekatan kualitatif bertujuan untuk mendeskripsikan hasil penelitian mengenai analisis kesalahan dengan mengumpulkan informasi sesuai prosedur pengumpulan data. Nawawi (2015) mengatakan bahwa "Metode Deskriptif dapat diartikan sebagai prosedur pemecahan masalah yang diselidiki dengan menggambarkan/melukiskan keadaan subyek/obyek penelitian (seseorang, lembaga, masyarakat dan lain-lain) pada saat sekarang berdasarkan fakta-fakta yang tampak, atau sebagai adanya" (p.67). Sejalan dengan Yusuf (2019) mengatakan bahwa "Pendekatan kualitatif dapat digunakan apabila ingin melihat dan mengungkapkan suatu keadaan maupun suatu objek dalam konteksnya; menemukan makna (meaning) atau pemahaman yang mendalam tentang sesuatu masalah yang dihadapi, yang tampak dalam bentuk data kualitatif, baik berupa gambar, kata, maupun kejadian serta dalam natural setting" (p.43).
Teknik pengumpulan data dalam penelitian ini menggunakan teknik tes dan wawancara. Alat pengumpul data yang digunakan dalam penelitian ini diantaranya, yaitu: (1) Soal uraian atau essay yang membahas tentang materi FPB dan KPK di kelas IV sekolah dasar. Tes berbentuk uraian dipilih agar data yang dikumpulkan dapat menimbulkan jawaban siswa berupa langkahlangkah dalam memperoleh hasil. Dari jawaban tes berbentuk uraian yang dikerjakan siswa tersebut akan terlihat apakah terdapat kesalahan atau tidak yang telah dilakukan siswa dalam mengerjakan soal-soal tersebut. (2) Pedoman wawancara yang digunakan berupa pedoman wawancara tidak terstruktur. Peneliti menyiapkan pedoman wawancara berupa daftar pertanyaan secara garis besar saja namun pertanyaan dapat berkembang lebih luas sesuai dengan informasi yang didapatkan. Dalam penelitian ini peneliti akan mewawancarai pihak yang dijadikan narasumber, yaitu Siswa Kelas IV Sekolah Dasar Negeri 01 Balai Karangan yang melakukan kesalahan-kesalahan dalam mengerjakan soal KPK dan FPB.

Data penelitian ini disajikan secara deskriptif dengan pendekatan kualitatif sehingga peneliti memilih teknik analisis data model Miles dan Huberman. Peneliti memilih model Miles dan Huberman karena analisis data kualitatif dilakukan secara interaktif dan sesuai dengan teknik pengumpulan data yang digunakan, yaitu menggunakan teknik pengumpulan data yang berbeda-beda, yaitu tes dan wawancara sedangkan dokumentasi hanya sebagai pelengkap sehingga tidak dijelaskan secara rinci.

Analisis model Miles dan Huberman dikemukakan dalam tiga tahapan, yaitu: (1) reduksi data, peneliti melakukan seleksi data, merangkum, memilah hal-hal yang pokok, dan memfokuskan pada hal-hal yang dikaji; (2) penyajian data, peneliti menyusun dan merapikan data dalam bentuk deskriptif agar lebih mudah memahami data yang didapat; dan (3) penarikan kesimpulan, peneliti menjawab rumusan masalah penelitian berdasarkan hasil dari analisis data yang diperoleh. Penarikan kesimpulan disusun 
dalam bentuk deskriptif yang berpedoman pada kajian dari pengamatan peneliti selama berada di lapangan.

\section{HASIL PENELITIAN \& PEMBAHASAN Jenis dan Faktor Penyebab Kesalahan}

Data ini dibuat dalam bentuk tabel rekapitulasi untuk menampilkan jenis kesalahan secara keseluruhan. Kemudian data tersebut akan dijabarkan dalam bentuk penjelasan. Kemudian dipaparkan juga faktor penyebab siswa melakukan kesalahan. Faktor penyebab dari penelitian ini lebih memperhatikan kesalahan dari diri siswa sendiri (intern/internal). Dengan wawancara akan tampak penyebab siswa melakukan kesalahan. Adapun data jenis kesalahan yyang dilakukan siswa menyelesaiakan soal KPK dan FPB dapat dilihat pada Tabel 1 berikut ini.

Tabel 1. Jenis Kesalahan Siswa Berdasarkan Prosedur Newman Persentase Jenis Kesalahan Tiap Soal

\begin{tabular}{clccccc}
\multirow{2}{*}{ No. } & Jenis Kesalahan & \multicolumn{4}{c}{$(\mathbf{\%})$} & Rata- \\
\cline { 3 - 6 } & & Nomor & Nomor & Nomor & Nomor & rata \\
& & $\mathbf{1}$ & $\mathbf{2}$ & $\mathbf{3}$ & $\mathbf{4}$ & \\
\hline 1 & Memahami Soal & 35,71 & 39,29 & 50 & 96,43 & 55,36 \\
\hline 2 & Mentransformasikan & 46,43 & 42,86 & 64,29 & 82,14 & 58,93 \\
\hline 3 & Keterampilan Proses & 67,86 & 78,57 & 89,29 & 96,43 & 83,04 \\
\hline 4 & Penulisan Jawaban Akhir & 67,86 & 92,86 & 96,43 & 96,43 & 88,39 \\
\hline
\end{tabular}

Data tersebut mendeskripsikan bahwa siswa lebih banyak melakukan kesalahan pada jenis kesalahan keterampilan proses dan penulisan hasil akhir. Keterampilan proses melibatkan proses komputasi atau operasi hitung serta tahapan-tahapan proses penyelesaian sedangkan penulisan jawaban akhir terkait keputusan atau kesimpulan yang diberikan di akhir jawaban.

Dari data tersebut dilihat dari prosedur Newman dapat dibuat sebagai berikut:

\section{Jenis kesalahan memahami soal (comprehension errors)}

Berdasarkan hasil analisis yang telah dilakukan pada 28 siswa saat menyelesaikan tes berupa soal KPK dan FPB yang telah diberikan, ditemukan sebanyak 55,36\% siswa yang melakukan jenis kesalahan memahami soal pada soal nomor 1 sampai dengan nomor 4 . Hal ini menunjukkan bahwa kemampuan siswa dalam memahami soal uraian masih kurang, terutama dalam bentuk soal nomor 4 yang berbentuk cerita dan didukung oleh Ini membuktikan bahwa walaupun semua siswa kelas IV SD Negeri 01 Balai Karangan semua bisa membaca dengan lancar dan lantang namun apabila belum memahami maksud dari soal, maka siswa tersebut dikatakan mengalami kesalahan dalam memahami soal. Dari hasil penelitian terlihat bahwa siswa lebih banyak tidak menuliskan informasi yang "diketahui" dan "ditanya" dari soal sehingga hal itu dianggap salah.

Berdasarkan hasil analisis kesalahan siswa dalam memahami soal KPK dan FPB, dengan jumlah siswa sebanyak 28 orang serta berdasarkan prosedur Newman, ditemukan beberapa faktor penyebab terjadinya kesalahan tersebut. Dari hasil analisis wawancara ternyata faktor penyebab yang paling berpengaruh adalah dari diri siswa sendiri, yaitu: 1) tidak teliti dalam menentukan hal yang diketahui dan ditanya dari soal. 2) tidak bisa menentukan hal yang diketahui dan ditanya dari soal. 3) lupa menuliskan hal yang diketahui dan ditanya dari soal. 4) tidak terbiasa menuliskan hal yang diketahui dan ditanya dari soal. 5) tidak mengerti maksud dari hal yang diketahui dan ditanya dari soal. 


\section{Jenis kesalahan transformasi (transformation error)}

Berdasarkan dari hasil analisis dari 28 siswa ditemukan sebanyak 58,93\% siswa yang melakukan jenis kesalahan transformasi yaitu pada soal nomor 1 sampai dengan nomor 4. Dari hasil penelitian ditemukan bahwa siswa melakukan kesalahan karena tidak menuliskan strategi penyelesaian dan salah menuliskan strategi penyelesaian yang mana seharusnya menggunakan rumus untuk KPK akan tetapi siswa menuliskan rumus FPB begitu juga sebaliknya. Kesalahan transformasi menuntut siswa untuk bisa menentukan strategi atau rumus yang digunakan, namun dari hasil penelitian terlihat bahwa kurangnya kemampuan siswa dalam menguasai materi KPK dan FPB membuat siswa tidak bisa menuliskan bahkan keliru dalam menentukan strategi penyelesaian yang seharusnya.

Berdasarkan hasil analisis kesalahan siswa dalam transformasi atau yang mudah dipahami dengan istilah strategi penyelesaian KPK dan FPB, dari hasil analisis wawancara, ditemukan bahwa pada jenis kesalahan ini siswa memiliki kekurangan kemampuan dalam menentukan strategi penyelesaian. Siswa yang melakukan kesalahan transformasi menyebabkan jawaban selanjutnya salah total. Prosedur Newman bersifat bertahap, dengan kata lain ketika siswa telah salah menentukan langkah dalam rencana yang akan diambil maka akan berdampak pada jawaban berikutnya. Hasil dari analisis wawancara terhadap siswa, peneliti mengambil kesimpulan dari jawaban siswa sebagai berikut: 1) tidak tahu harus menggunakan bentuk penyelesaian yang seharusnya digunakan. 2) bingung dalam menentukan bentuk penyelesaian yang seharusnya. 3) kurangnya kemampuan dalam penguasaan materi. 4) kurangnya kemampuan dalam mengerti bentuk penyelesaian yang digunakan. Jawaban siswa tersebut merupakan bagian dari faktor penyebab yang berasal dari dalam diri siswa itu sendiri (intern).

\section{Jenis kesalahan keterampilan proses (process skill)}

Berdasarkan hasil analisis dari 28 siswa ditemukan sebanyak $83,04 \%$ siswa yang melakukan jenis kesalahan keterampilan proses yaitu pada soal nomor 1 sampai dengan nomor 4. Dari hasil penelitian, tampak bahwa siswa memiliki keterampilan proses dalam menyelesaikan soal matematika terutama KPK dan FPB masih rendah. Dari analisis hasil tes yang diberikan kepada siswa untuk melihat sejauh mana kesalahan pada keterampilan proses, diperoleh bahwa masih banyak siswa tidak bisa atau salah saat menentukan langkah pengerjaan berikutnya bahkan bingung langkah selanjutnya harus seperti apa, salah dalam menentukan simbol operasi hitung yang seharusnya perkalian menjadi penjumlahan dan salah dalam berhitung atau bisa dikatakan bahwa siswa tidak menguasai kemampuan dasar operasi hitung.

Berdasarkan hasil analisis kesalahan siswa dalam menyelesaikan soal KPK dan FPB pada 9 siswa sebagai subjek penelitian yang menjadi perwakilan telah melakukan wawancara diperoleh bahwa siswa banyak yang tidak menguasai perkalian dan pembagian. Dapat dikatakan bahwa siswa memiliki kemampuan operasi hitung yang sangat memperihatinkan. Padahal, operasi hitung merupakan kompetensi dasar dalam matematika. Sangat disayangkan pada saat wawancara dilakukan, kebanyakan subjek wawancara bingung harus apa langkah penyelesaian yang seharusnya dan benar atau salah jawaban yang mereka tuliskan karena peneliti tidak bisa membantu saat subjek penelitian menyelesaikan apa yang diminta. Pada saat wawancara terhadap siswa, tampak 5 dari 9 siswa bingung harus melakukan langkah proses penyelesaian dan 8 dari 9 siswa masih menghitung dengan jari dan 
juga coret-coret seperti garis vertikal kecil yang menyerupai lidi untuk melakukan operasi hitung baik itu perkalian maupun pembagian. Maka didapat hasil faktor penyebab siswa melakukan jenis kesalahan keterampilan proses adalah sebagai berikut: 1) Ketidakmampuan subjek penelitian dalam melakukan operasi hitung. 2) Ketidaktelitian subjek penelitian dalam melakukan operasi hitung. 3) Asal-asalan dalam meletakkan hasil perhitungan. 4) Tergesa-gesa dalam mengerjakan.

\section{Jenis kesalahan penulisan jawaban akhir (encoding error)}

Berdasarkan hasil analisis dari 28 siswa ditemukan sebanyak $88,39 \%$ siswa yang melakukan jenis kesalahan penulisan jawaban akhir yaitu pada soal nomor 1 sampai nomor 4. Dari hasil analisis yang telah dilakukan, diperoleh bahwa lebih banyak siswa melakukan kesalahan pada penulisan jawaban akhir. Prosedur Newman yang menganalisis jawaban secara bertahap menggambarkan kemampuan siswa yang saling terhubung dari satu tahap ke tahap berikutnya. Jika pada tahap awal sudah salah maka tahap berikutnya juga salah apalagi pada tahap akhir. Pada tahap ini, ketelitian siswa juga terlihat, sedikit saja keliru maka jawaban akan salah. Walaupun dari tahap awal sampai keterampilan proses sudah benar tapi tidak teliti dalam menuliskan jawaban maka siswa dikatakan mengalami kesalahan penulisan jawaban akhir. Hal ini terlihat dari jawaban siswa, ada yang tidak tahu tahap sebelumnya sehingga tidak menuliskan jawaban dan bahkan mengisi jawaban dengan asal tulis, ada yang tahu tahap sebelumnya tapi melakukan kecerobohan yang menyebabkan salah dalam menuliskan jawaban akhir.

Berdasarkan hasil analisis kesalahan siswa terhadap 9 subjek penelitian dari 28 siswa sebagai perwakilan telah melakukan wawancara untuk mengetahui faktor penyebab terjadinya kesalahan penulisan jawaban akhir, diperoleh bahwa beberapa siswa sengaja tidak menuliskan jawaban akhir dan sembarangan menentukan jawaban akhir disebabkan tidak menguasai proses penyelesaian KPK dan FPB. Siswa yang yakin akan jawabannya benar tapi pada kenyataan setelah dikoreksi salah, berarti siswa tersebut tidak teliti dan tergesa-gesa menetapkan keputusan dalam menuliskan jawaban akhir. Sedangkan siswa yang masih raguragu dalam menjawab pertanyaan tersebut tapi jawabannya salah, berarti siswa tersebut hanya menuliskan jawaban acak atau asal-asalan. Dari analisis tes pada lembar jawaban siswa yang melakukan kesalahan penulisan jawaban akhir, beberapa jawaban siswa menampilkan ketidaksesuaian jawaban dari proses penyelesaian yang dikerjakan. Terlihat dari jawaban siswa hanya tampak jawaban akhir saja tanpa proses dan ada juga yang tidak menuliskan jawaban akhir. Dari hasil analisis wawancara, ternyata faktor penyebab subjek penelitian melakukan jenis kesalahan penulisan jawaban akhir adalah sebagai berikut: 1) tidak mengerti menentukan jawaban akhir yang benar 2) tidak bisa menentukan jawaban akhir karena kesalahan dari proses penyelesaian sebelumnya 3) tidak mengecek kembali jawaban yang dikerjakan dan 4) tidak teliti.

Sedangkan faktor penyebab secara eksternal atau dari luar diri siswa, berdasarkan hasil analisis dengan melakukan wawancara kepada 9 siswa sebagai perwakilan untuk mengetahui faktor penyebab siswa melakukan kesalahan dalam menyelesaikan soal KPK dan FPB ternyata 5 dari 9 siswa mengatakan bahwa tidak menyukai matematika. Semua siswa yang menjadi subjek wawancara mengatakan KPK dan FPB merupakan materi yang sulit dipahami, langkah pengerjaannya yang berbelit-belit serta membuat bingung. Ketertarikan siswa terhadap matematika terutama pada KPK dan FPB juga tampak kurang. Hal ini dipaparkan siswa karena kurangnya minat terhadap matematika 
disebabkan kurangnya sarana dan prasarana penunjang, cara mengajar yang monoton, serta dorongan dari guru dalam pembelajaran KPK dan FPB. Minimnya motivasi keluarga terhadap matematika juga dapat mempengaruhi kemampuan siswa dalam menguasai konsep dasar matematika terutama pada operasi hitung dan langkah pengerjaan dalam memecahkan masalah matematika seperti KPK dan FPB. Dari hasil analisis wawancara diperoleh alasan-alasan yang dipaparkan siswa tentang penyebab siswa melakukan kesalahan-kesalahan dalam menyelesaikan soal KPK dan FPB berdasarkan Newman sebagai berikut. (1) Kurangnya perhatian dan bimbingan keluarga terhadap kegiatan sekolah. Hal itu terlihat ketika siswa mendapatkan tugas atau ketika siswa kesulitan mengerjakan tugas barulah ada bimbingan dari keluarga. Apabila tidak ada tugas, maka siswa tidak mendapatkan motivasi belajar di rumah. (2) Guru kurang menekankan penanaman dan penguatan konsep, metode pembelajaran yang monoton, tidak mengunakan media saat pembelajaran. (3) Pergaulan siswa yang berlebihan. Sehingga lebih banyak bermain dari pada mengulang pelajaran. (4) Penggunaan alat media elektronik yang tidak digunakan untuk pembelajaran tapi lebih ke sosial media.

Dalam penelitian ini, jenis kesalahan penulisan jawaban akhir menjadi jenis kesalahan yang paling banyak dilakukan oleh siswa yaitu sebesar $88,39 \%$. Hal ini sesuai dengan penelitian Humaerah (2017) yang mengatakan bahwa berdasarkan hasil perhitungan persentase tiap jenis kesalahan didapatkan bahwa kesalahan terbesar yang dilakukan siswa yaitu pada jenis kesalahan penentuan jawaban akhir sedangkan kesalahan terkecil yang dilakukan siswa yaitu pada jenis kesalahan membaca (p.63). Di sini peneliti tidak mencantumkan kesalahan membaca karena pada instrumen tes pada soal peneliti tidak banyak melibatkan simbolsimbol matematika. Namun, pada saat wawancara peneliti tetap mengamati kemampuan subjek penelitian dalam membaca. Pada saat wawancara terlihat siswa juga sudah bisa membaca dengan lancar.

\section{SIMPULAN DAN SARAN \\ Simpulan}

Berdasarkan dari hasil dan pembahasan dapat disimpulkan sebagai berikut. (1) Hampir seluruh partisipan penelitian melakukan kesalahan pada semua jenis kesalahan dengan jumlah yang berbeda-beda tiap soalnya. Adapun jenis-jenis kesalahan berdasarkan prosedur Newman, yaitu kesalahan memahami soal (comprehension error), kesalahan transformasi (transformation error), kesalahan keterampilan proses (process skill error) dan kesalahan menuliskan jawaban akhir (encoding error). Dari semua jenis kesalahan tersebut dapat disimpulkan bahwa kesalahan menuliskan jawaban akhir yang paling banyak terjadi. (2) Faktor penyebab kesalahan yang dilakukan siswa dalam menyelesaikan soal KPK dan FPB terdiri dari faktor internal dan eksternal. (a) Faktor internal, yaitu tidak teliti, mudah lupa, tidak mengerti, bingung, tergesa-gesa, tidak terbiasa mengerjakan soal uraian, kurangnya kemampuan dalam penguasaan materi, kurangnya kemampuan dalam mengerti bentuk penyelesaian yang digunakan, ketidakmampuan operasi hitung, asal-asalan dalam menyelesaiakan soal, tidak membiasakan diri untuk mengulang kembali contoh-contoh dalam mengerjakan soal, tidak memotivasi diri untuk giat menguasai operasi hitung atau aritmatik. (b) Faktor eksternal, yaitu kurangnya perhatian dan bimbingan keluarga terhadap kegiatan sekolah, guru kurang menekankan penanaman serta penguatan konsep, metode pembelajaran yang monoton, tidak mengunakan media saat pembelajaran, pergaulan siswa yang berlebihan, penggunaan alat media elektronik yang tidak digunakan untuk pembelajaran tapi lebih ke sosial media.

\section{Saran}

Beberapa saran sebagai berikut: (1) Untuk meningkatkan kemampuan memahami soal sebaiknya dibiasakan dengan 
mengaitkan dengan kehidupan sehari-hari. Untuk meningkatkan penguasaan transformasi hendaknya siswa ditekankan dalam memahami bentuk atau strategi penyelesaian daripada dihapal. Sedangkan untuk meningkatkan kemampuan keterampilan proses sebaiknya siswa memperbanyak melatih diri mengerjakan soal dan memperkuat operasi hitung di rumah. (2) Guru sebaiknya membuat pembelajaran yang menyenangkan dengan lebih menekankan pada penanaman konsep, mencari solusi atau memberikan bimbingan secara intensif bagi siswa yang mengalami kesalahan dalam mengerjakan soal matematika dan siswa yang memiliki kemampuan kognitif rendah. (3) Motivasi, bimbingan, dan perhatian orang tua maupun saudara dalam pembelajaran matematika harus diberikan kepada siswa agar lebih giat dalam menguasai konsep dasar dan kemampuan dasar matematika.

\section{DAFTAR RUJUKAN}

Ayuwirdayana, A. (2019). Analisis Kesalahan Siswa Dalam Menyelesaikan Soal Cerita Matematika Berdasarkan Prosedur Newman di MTsN 4 Banda Aceh. Skripsi. Banda Aceh: Universitas Islam Negeri Ar-Raniry Darussalam. 1135. Diakses dari http://repository.arraniry.ac.id/id/eprint/ 10269/.

Hadi, S., Novaliyosi (2019). Timss Indonesia (Trends In International Mathematics And Science Study). Prosiding Seminar Nasional \& Call For Papers: Program Studi Magister Pendidikan Matematika Universitas Siliwangi Tasikmalaya. 562569. Diakses dari http://jurnal.unsil. ac.id/index.php/sncp/article/view/1096.

Humaerah, S. R. (2017). Analisis Kesalahan Siswa dalam Menyelesaikan Soal-soal
Pada Materi Geometri dengan Prosedur Newman Kelas VIII MTs Muhammadiyah Tenetea Kabupaten Jeneponto. Skripsi. Makasar: Universitas Islam Negeri Makasar. 1148. Diakses dari http://repositori.uinalauddin.ac.id/id/ eprint/7766.

Jha, S. K. (2012). Mathematics Performance of Primary School Students in Assam (India): An Analysis Using Newman Procedure. International Journal of Computer Applicatios in Engineering Science. 2 (1). ISSN: 2231-4946. Doi: 10.1.1.303.2464.

Muhsetyo. (2014). Pembelajaran Matematika $S D$. Tangerang Selatan: Universitas Terbuka.

Nawawi, H. (2015). Metode Penelitian Bidang Sosial. Yogyakarta: Gadjah Mada University Press.

Prakitipong, N., Nakamura, S. (2006). Analysis of Mathematics Performance of Grade Five Students in Thailand Using Newman Procedure. CICE Hiroshima University, Journal of International Cooperation in Education. 9 (1). 111-122. Doi: 10.15027/34243.

Sugiyono. (2017). Metode Penelitian Kualitatif, Kuantitatif, dan $R$ \& $D$. Bandung: Alfabeta.

Suryanto, A., Djatmiko, T. (2012). Evaluasi Pembelajaran di SD. Tangerang Selatan: Universitas Terbuka.

Yusuf, M. (2014). Metode Penelitian: Kuantitatif, Kualitatif \& Penelitian Gabungan. Jakarta: Kencana. 